\title{
Partisipasi Masyarakat dalam Penyediaan Air Minum dan Sanitasi Berbasis Masyarakat (PAMSIMAS) di Kecamatan Simpur Kabupaten Hulu Sungai Selatan
}

\author{
Taufik Afriadi' ${ }^{1}$, Hadi Wahyono ${ }^{2}$
}

Diterima : 15 Agustus 2012

Disetujui : 12 September 2012

\begin{abstract}
The study examines the gap between expectations and realization of PAMSIMAS (Program 'Air Minum dan Sanitasi Berbasis Masyarakat - Community Based Drinking Water and Sanitation Program) in Simpur District, Hulu Sungai Selatan Regency in Borneo, which has been implemented starting in 2008 in three villages, namely Garunggung, Ulin and Pantai Ulin. However, Garunggung and Ulin have also received Village Incentive Grant (Hibah Insentif Desa - HID) from the government, and Pantai Ulin has not. The study focuses on the level of participation of the people, comparing the villages having received the HID and those not. The study found differences in planning, implementation, as well as operation and maintenance of the PAMSIMAS in the villages having received HID and those not. For example the study found differences in planning in terms of interference from stakeholders and accommodation of interests. Education and occupation have become the dominant factor affecting participation level. Education influences knowledge and awareness, while occupation, having close connection to income, influences the availability of time to participate.
\end{abstract}

Key words : participation, PAMSIMAS, Village Incentive Grant (HID - Hibah Insentif Desa)

\begin{abstract}
ABSTRAK
Studi ini mengkaji kesenjangan harapan dan realisasi kegiatan PAMSIMAS di Kecamatan Simpur, Kabupaten Hulu Sungai Selatan, Kalimantan, yang telah diimplementasikan sejak 2008 di tiga desa, yaitu Garunggung, Ulin dan Pantai Ulin. Pada kenyataannya, desa Garunggung dan Ulin juga menerima Hibah Insentif Desa - HID dari pemerintah, sedangkan Pantai Ulin belum. Studi ini fokus kepada tingkat partisipasi, membandingkan desa yang menerima HID dan yang tidak. Studi ini menemukan perbedaan dalam hal perencanaan, implementasi serta operasi dan perawatan program PAMSIMAS di desa yang menerima HID dan yang tidak. Sebagai contoh terdapat perbedaan dalam hal perencanaan terkait campur tangan stakeholder dan pengakomodasian kepentingan. Pendidikan dan pekerjaan merupakan faktor dominan yang mempengaruhi tingkat partisipasi. Pendidikan mempengaruhi pengetahuan dan kesadaran, sedangkan pekerjaan, yang terkait erat dengan pendapatan, mempengaruhi ketersediaan waktu untuk berpartisipasi.
\end{abstract}

Kata kunci : partisipasi, PAMSIMAS, HID - Hibah Insentif Desa

\footnotetext{
${ }^{1}$ Dinas PU Kabupaten Hulu Sungai Selatan, Kalimantan Selatan

${ }^{2}$ Dosen Jurusan Perencanaan Wilayah dan Kota, Undip, Semarang, Jawa Tengah

Kontak Penulis : ms.afri_81@yahoo.co.id
} 


\section{PENDAHULUAN}

Air minum dan sanitasi merupakan sektor infrastruktur yang penting dalam rangka peningkatan derajat kesehatan masyarakat, terutama dalam menurunkan angka penyakit yang ditularkan melalui air dan lingkungan. Dewasa ini, masih banyak warga di seluruh Indonesia yang kesulitan mengakses air bersih dan sarana sanitasi karena keterbatasan infrastruktur yang ada. Sesuai dengan target Millenium Development Goals (MDGs), Pemerintah telah menetapkan target pada 2015 bahwa sebanyak 68,87\% dari total penduduk Indonesia harus memiliki akses terhadap sumber air minum layak, sementara akses terhadap fasilitas sanitasi yang layak adalah sebanyak $62,41 \%$. Pemenuhan akan pelayanan air minum dan sanitasi dilakukan melalui dua sektor pendekatan, yang pertama melaui badan, atau lembaga dinas terkait dan yang kedua melalui pendekatan berbasis masyarakat.

Salah satu program infrastruktur air minum dan sanitasi yang melibatkan masyarakat adalah Program Penyediaan Air Minum dan Sanitasi Berbasis Masyarakat (PAMSIMAS) yang melibatkan berbagai stakeholder baik yang berada di tingkat pusat, provinsi, maupun daerah. Program berbasis masyarakat ini merupakan dukungan dari Bank Dunia dengan melibatkan berbagai unsur pemerintah antara lain Bappenas, Departemen Pekerjaan Umum, Departemen Dalam Negeri dan Departemen Keuangan. Sesuai dengan prinsipnya yang berbasis masyarakat maka peran serta aktif masyarakat itu sendiri yang menjadi faktor kunci keberhasilan dalam pelaksanaan program tersebut.

Sebagai salah satu penerima bantuan Program PAMSIMAS, Kabupaten Hulu Sungai Selatan telah melaksanakan kegiatan berbasis masyarakat ini sejak tahun 2008 sampai dengan tahun 2011. Jumlah desa yang menerima bantuan pada tahun 2008 adalah 9 (sembilan) desa sasaran di 2 (dua) kecamatan yaitu Kecamatan Telaga Langsat dan Kecamatan Angkinang. Tahun 2009 sebanyak 15 desa sasaran di 4 (empat) kecamatan yaitu Kecamatan Loksado, Kecamatan Simpur, Kecamatan Kalumpang dan Kecamatan Daha Selatan. Tahun 2010 sebanyak 12 desa sasaran di 5 (lima) kecamatan yaitu Kecamatan Sungai Raya, Kecamatan Angkinang, Kecamatan Daha Utara, Kecamatan Kandangan dan Kecamatan Simpur. dan pada tahun 2011 ini sebanyak 16 desa sasaran di 7 (tujuh) kecamatan yaitu Kecamatan Sungai Raya, Kecamatan Simpur, Kecamatan Kalumpang, Kecamatan Telaga Langsat, Kecamatan Daha Utara, Kecamatan Loksado dan Kecamatan Padang Batung.

Kegiatan dalam Program PAMSIMAS yang dilaksanakan berupa fisik dan non fisik yang kesemuanya berbasis masyarakat. Kegiatan fisik berupa pembangunan sarana air bersih dan sanitasi seperti : pembuatan hidran umum, sumur gali, sumur pompa tangan, dan lain-lain. Kegiatan non fisik seperti : peyuluhan PHBS, limbah cair, penggunaan jamban sehat, cuci tangan, gigi mulut; pelatihan dan peningkatan PHS (sampah, teknis sarana PHS, peningkatan kapasitas PHBS utk kader); pelatihan administrasi dan keuangan; dan pelatihan teknik fisik. Selama tiga tahun sejak program dilaksanakan, pada desa sasaran PAMSIMAS masih ada kesenjangan antara harapan dengan kenyataan yang terjadi seperti : masih adanya praktek buang air besar sembarangan (BABS), belum optimalnya fungsi kapasitas masyarakat dan kelembagaan lokal yang ada, belum berkesinambungannya sarana dan prasarana air minum dan sanitasi yang dibangunan untuk jangka panjang, masih kurangnya peran serta perempuan dalam proses kegiatan, dan sebagainya.

Fakta yang dijumpai di lapangan ada dua desa yang menerima insentif tambahan atau Hibah Insentif Desa (HID) sebagai cerminan keberhasilan dari pemerintah pusat yaitu Desa Garunggang dan Desa Ulin di Kecamatan Simpur yang melaksanakan kegiatan PAMSIMAS pada 
tahun 2009. Padahal pada tahun yang sama di Kecamatan Simpur, ada satu desa lagi yang melaksanakan program tersebut, yaitu Desa Pantai Ulin. Sebelumnya dilakukan evaluasi dan penilaian terhadap desa sasaran PAMSIMAS namun hanya dua tersebut yang memenuhi syarat. Terhadap kedua desa tersebut setelah dilakukan verifikasi oleh Tim Penilai Pusat dianggap sudah memenuhi target capaian program yaitu pencapaian cakupan layanan $>70 \%$, sarana air minum dan sanitasi yang telah dibangun $100 \%$ bermanfaat bagi rumah tangga miskin, potensi sumber daya air $>0,4 \mathrm{It} / \mathrm{det}$, stop BABS sembarangan $100 \%$ yang dibuktikan dengan komitmen jika ada yang warga yang melanggar maka dikenakan denda, dan tidak ada catatan penyimpangan dari penggunaan dan, oleh karena itu kedua desa tersebut dianggap berhasil. Pada setiap desa sasaran sejak awal pelaksanaan kegiatan mereka selalu dipacu dan diberi pengertian bahwa ada penghargaan bagi yang telah melaksanakan dan menghasilkan output dan outcome yang memuaskan. Hal ini sangat disayangkan kenapa hanya dua desa yang bisa mendapatkan Hibah Insentif Desa (HID), padahal setiap desa mempunyai kesempatan yang sama untuk berkompetisi. Ini menjadi satu fenomena, kenapa pada tiga desa dalam satu lingkup kecamatan terdapat perbedaan hasil yang cukup signifikan.

Keberhasilan pelaksanaan program PAMSIMAS baik ditinjau dari segi pembangunan fisik dan non fisik akan membantu pemerintah Kabupaten Hulu Sungai Selatan dalam rangka penyediaan air minum dan sanitasi, baik dalam jangka pendek maupun jangka panjang. Hasil yang baik dari program yang berbasis masyarakat akan tercapai jika masyarakat berpartisipasi aktif dalam kegiatan. Dengan berpartisipasi aktif, akan menumbuhkan rasa memiliki terhadap apa yang mereka bangun, sehingga keberlanjutan dan kebersinambungan akan terus berlangsung. Oleh karena itu, perlu dilakukan sebuah penelitian secara mendalam ditinjau dari partisipasi masyarakat dalam rangka mendukung keberhasilan program yang berbasiskan masyarakat terutama dalam bidang air minum dan sanitasi di Kabupaten Hulu Sungai Selatan.

\section{METODE PENELITIAN}

Penelitian ini menggunakan pendekatan deskriptif kuantitatif yang menitikberatkan pada penelitian lapangan dengan data dari masyarakat sebagai data primer. Pendekatan deskriptif kuantitatif pada penelitian ini ditujukan untuk menjelaskan secara sistematis terhadap kondisi faktual terhadap Desa (HID) dan Desa Non HID, dengan menganalisis variabel-variabel yang telah ditentukan sebelumnya. Teknik sampling yang digunakan adalah Area Probability Sampling yang dilengkapi dengan proportional sampling dengan pertimbangan semua unsur masyarakat mempunyai kesempatan yang sama untuk terlibat dalam kegiatan (kaya, miskin, laki-laki, perempuan, tua dan muda), jumlah penduduk di ketiga desa yang dijadikan penelitian tidak seimbang, sehingga proporsinya perlu dipertimbangkan, dan bertujuan untuk mengambil wakil sampel yang dari setiap desa yang akan diteliti. Secara garis besar teknik analisis yang dilakukan dalam penelitian ini ada empat yaitu : analisis deskriptif, distribusi frekuensi, analisis perbandingan, dan analisis tabulasi silang.

\section{GAMBARAN UMUM WILAYAH STUDI}

Kecamatan Simpur merupakan satu dari sebelas kecamatan di Kabupaten Hulu Sungai Selatan dengan ibu kotanya Simpur. Luas wilayah sebesar $82,35 \mathrm{~km}^{2}$ terdiri dari 11 desa yaitu Desa Amparaya, Desa Garunggang, Desa Kapuh, Desa Panjampang Bahagia, Desa Pantai Ulin, Desa Simpur, Desa Tebing Tinggi, Desa Ulin, Desa Wasah Hilir, Desa Wasah Hulu, dan Desa Wasah Tengah. Batas administrasi Kecamatan Simpur adalah sebelah barat berbatasan dengan 
Kecamatan Kalumpang, sebelah utara dan timur berbatasan dengan Kecamatan Kandangan, serta sebelah selatan berbatasan dengan Kecamatan Sungai Raya. Jumlah penduduk pada tahun 2009 adalah 13.712 jiwa dengan luas wilayah 82,35 adalah $\mathrm{km}^{2}$. Mata pencaharian sebagian besar penduduknya adalah petani dan pedagang. Jumlah penduduk laki-laki sebanyak 6.624 jiwa dan penduduk wanita berjumlah 7.088 jiwa. Ditinjau menurut tingkat kesejahteraan penduduk di Kecamatan Simpur menurut data terakhir (tahun 2009) terdapat 544 rumah tangga sasaran (RTS) kategori hampir miskin dan 231 RTS kategori miskin. Dari sebelas desa di Kecamatan Simpur, sudah delapan desa yang melaksanakan Program PAMSIMAS terhitung sejak dimulainya Program pada tahun 2008.

\section{KAJIAN PARTISIPASI MASYARAKAT DALAM PENYEDIAAN AIR MINUM DAN SANITASI BERBASIS MASYARAKAT (PAMSIMAS) DI KECAMATAN SIMPUR}

Dalam konteks pembangunan, partipasi berarti kerjasama antara rakyat dan pemerintah dalam merencanakan, melaksanakan, dan mengembangkan hasilnya (Soetrisno, 1995:207). Keterlibatan masyarakat sesuai dengan hak dan kewajibannya adalah sebagai subjek dan objek pembangunan. Partisipasi meningkatkan kepekaan masyarakat untuk menerima dan menanggapi program-program pembangunan. Partisipasi juga dapat diartikan sebagai kontibusi secara sukarela dari masyarakat kepada proyek tanpa turut serta mengambil keputusan. Adanya dialog masyarakat setempat dengan para pelaku yang melakukan kegiatan pelaksanaan mutlak dilakukan agar memperoleh informasi lokal dan dampak sosial yang mungkin terjadi. Menurut FAO dalam Mikkelsen (2003:64) partisipasi adalah suatu proses aktif yang mengandung arti bahwa orang atau kelompok terkait mempunyai inisiatif dan menggunakan kebebasannya untuk melakukan sesuatu.

Kekuatan partisipasi adalah terletak sejauh mana masyarakat terlibat dalam suatu kegiatan. Hubungan tingkat partisipasi dan tahapan program adalah sebagai bantuan untuk menguji alat dan teknik, tahapan pada proyek atau program PAMSIMAS dihubungkan dalam matriks dan pada ketelitian tingkat partisipasi seperti yang diungkapkan Hamdi (1997 : 69). Lebih lanjut dia membagi tingkatan partisipasi menjadi 5 (lima) yaitu : None, pihak luar (outsider) bertanggung jawab penuh kepada semua pihak tanpa campur tangan dari masyarakat; Indirect, sama dengan tidak ada partisipasi tetapi informasi merupakan sesuatu yang spesifik; Consultation, pihak luar mendasarkan pada informasi yang diperoleh dari masyarakat. Keberhasilan partisipasi pada tingkatan ini tergantung dari kebenaran data dan kemampuan mengolah data; Shared, pihak luar dan masyarakat berinteraksi sejauh mungkin secara bersamaan demi mencapai tujuan bersama; dan Full Control, masyarakat mendominasi dan dapat meminta bantuan pihak luar sewaktu-waktu jika diperlukan.

Dalam pendekatan yang bersifat kemitraan terdapat perbedaan paradigma antara yang baru dengan yang lama, dimana paradigma lama cenderung berorientasi pada pemerintah (Budiati, 2012:139). Sedangkan untuk paradigma baru sudah ada prakarsa bersama, saling mengisi, dan jalin kepantingan antara pihak yang berkepentingan. Pelaksanaan kegiatan diawasi bersama dengan akuntabilitas yang tinggi dan transparan. Sekarang orientasi kegiatan tidak berdasarkan pada proyek, tapi lebih berdasarkan asas manfaat. Partisipasi masyarakat dalam pembangunan sangat dipengaruhi oleh faktor karakteristik masyarakat. Faktor-faktor tersebut menentukan bentuk dan tingkat partisipasi masyarakat yang berlangsung dalam suatu kegiatan. Pengaruh yang ada untuk setiap tempat adalah tidak sama, meskipun berlangsung dalam suatu wilayah yang berdekatan. Tidak hanya itu, kemampuan dari faktor untuk mempengaruhi setiap individu adalah tidak sama. Faktor-faktor internal yang mempengaruhi 
partisipasi masyarakat menurut Slamet (1994:97) adalah jenis kelamin, usia, tingkat pendidikan, tingkat pendapatan, lamanya tinggal, dan mata pencaharian.

Partisipasi yang diberikan oleh seorang pria dan wanita dalam pembangunan adalah berbeda karena adanya sistem sosial yang terbentuk yang membedakan kedudukan antara laki-laki dan wanita. Perbedaan kedudukan dan derajat ini, akan menimbulkan perbedaan-perbedaan hak dan kewajiban antara pria dan wanita. Menurut Soedarno et. al (1992) dalam Suciati (2005), bahwa di dalam sistem pelapisan atas dasar seksualitas ini, golongan pria memiliki sejumlah hak istimewa dibandingkan golongan wanita. Dengan demikian maka kecenderungannya, kelompok pria akan lebih banyak ikut berpartisipasi.

Dalam Pogram PAMSIMAS justru sebaliknya. Sesuai dengan prinsipnya kesetaraan jender, maka program ini memberikan kesempatan yang sama kepada perempuan seperti halnya lakilaki untuk berpartisipasi dalam perencanaan, pelaksanaan, dan pemeliharaan/pengelolaan kegiatan. Faktanya kegiatan yang berhubungan dengan sanitasi lebih banyak dilakukan kaum perempuan dalam aktivitas sehari-hari. Kebiasaan masyarakat umum biasanya terdapat perbedaan senioritas, sehingga muncul golongan tua, muda, yang berbeda-beda dalam hal tertentu. Misalnya dalam pengambilan keputusan. Usia berpengaruh pada keaktifan seseorang untuk berpartisipasi (Slamet dalam Suciati, 2005). Dalam hal ini golongan tua yang dianggap lebih berpengalaman atau senior, akan lebih banyak memberikan pendapat dan dalam hal menetapkan keputusan. Program PAMSIMAS yang berbasiskan masyarakat tidak memandang kepada golongan usia sehingga tua, muda, semua mempunyai hak yang sama dalam menyalurkan pendapat dan keputusan.

Salah satu ciri dalam pembangunan partisipatif dalam masyarakat adalah perbedaan pengetahuan tentang konsep partisipasi itu sendiri. Litwin (1986) dalam Suciati (2005) mengatakan bahwa, salah satu karakteristik partisan dalam pembangunan partisipatif adalah tingkat pengetahuan masyarakat tentang usaha partisipasi yang diberikan masyarakat dalam pembangunan. Pengetahuan ini dipengaruhi oleh tingkat pendidikan. Semakin tinggi latar belakang pendidikannya, tentunya mempunyai pengetahuan yang luas tentang pembangunan dan bentuk serta tata cara partisipasi yang dapat diberikan dan seseorang lebih mudah berkomunikasi dengan orang luar, dan cepat tanggap terhadap inovasi. Latar belakang pendidikan tidak menjadi halangan bagi seseorang untuk turut berpartisipasi dalam Program PAMSIMAS, sehingga setiap individu mempunyai hak untuk berperan sesuai dengan kadar kemampuan masing-masing, apakah tingkat pendidikan rendah maupun tinggi, sehingga prinsip kesamaan tetap terjaga.

Menurut Barros (1993) dalam Suciati (2005), bahwa penduduk yang lebih kaya kebanyakan membayar pengeluaran tunai dan jarang melakukan kerja fisik sendiri. Sementara penduduk yang berpenghasilan pas-pasan akan cenderung berpartisipasi dalam hal tenaga. Besarnya tingkat penghasilan akan memberikan peluang lebih besar kepada masyarakat untuk berpartisipasi dan juga berinvestasi. Program PAMSIMAS yang mempunyai sasaran kepada masyarakat miskin justru memberikan peluang kepada masyarakat lapisan bawah untuk mengambil peran lebih dominan sehingga seharusnya kemampuan finansial tidak menjadi halangan untuk berpartisipasi. Mata pencaharian seseorang berkaitan dengan tingkat penghasilan seseorang, oleh karena itu mata pencaharian dapat mempengaruhi masyarakat untuk berpartisipasi dalam pembangunan. Hal ini disebabkan karena pekerjaan akan berpengaruh terhadap waktu luang seseorang, misalnya dalam hal menghadiri pertemuan, kerja bakti dan sebagainya. 


\section{ANALISIS PARTISIPASI MASYARAKAT DALAM PROGRAM PENYEDIAAN AIR MINUM DAN SANITASI BERBASIS MASYARAKAT (PAMSIMAS) DI KECAMATAN SIMPUR}

Analisis yang dilakukan meliputi analisis terhadap pelaksanaan partisipasi masyarakat; analisis tingkat partisipasi masyarakat; analisis karakteristik responden; dan analisis komprehensif partisipasi masyarakat.

\section{Analisis Pelaksanaan Partisipasi Masyarakat}

Tujuan dari terhadap pelaksanaan partisipasi masyarakat adalah untuk mengidentifikasi kondisi pelaksanaan partisipasi masyarakat pada tahap perencanaan, implementasi, serta operasi dan pemeliharaan dalam Program PAMSIMAS di desa yang mendapat HID yaitu Desa Garunggang dan Desa Ulin serta desa yang tidak mendapat (Non) HID yaitu Desa Pantai Ulin yang dilakukan dengan analisis deskriptif kuantitatif menggunakan distribusi frekuensi. Untuk menganalisis kondisi pelaksanaan partisipasi masyarakat pada tahap perencanaan, implementasi, serta operasi dan pemeliharaan dalam Program PAMSIMAS di Desa Garunggang, Desa Ulin, dan Desa Pantai Ulin dilakukan dengan analisis deskriptif kuantitatif menggunakan distribusi frekuensi. Variabel yang dianalisis meliputi: inisiatif program, penggalian informasi, pengambilan keputusan, alokasi sumber daya, orientasi pelaksanaan, proses pelaksanaan, peranan individu, dan pemantauan.

Pada tahap perencanaan, jawaban responden tentang inisiatif program diperoleh komposisi yang seimbang antara Desa HID dan Desa Non HID. Perbedaan yang mencolok antara Desa HID dengan Desa Non HID adalah tentang ada tidaknya intervensi dari pihak luar. Lebih dari separuh responden pada Desa Non HID menjawab adanya campur tangan yang kuat dari pihak luar. Sedangkan pada Desa HID meskipun ada namun jauh lebih kecil. Proses pengambilan keputusan pada ketiga desa berlangsung sangat demokratis, namun pada Desa Non HID masih ada responden yang meragukan kepentingan semua pihak terakomodir.

Pada tahap implementasi, di Desa HID menurut sebagian besar responden keputusan perencanaan bisa diterapkan sepenuhnya. Kondisi ini berbanding terbalik dengan Desa Non HID, lebih dari sepertiga (32,76\%) responden menyatakan tidak bisa diterapkan sepenuhnya, dan hampir sepertiga $(27,59 \%)$ responden menyatakan keraguan adanya kontribusi dari pihak terkait. Hampir dari semua responden pada Desa HID menjawab bahwa pelaksanaan kegiatan berdasarkan asas manfaat, meski ada yang ragu-ragu namun prosentase relatif kecil $(5,56 \%)$, sedangkan pada desa Non HID lebih dari seperlima (25,86\%) responden meragukan hal itu. Perbedaan yang signifikan dalam proses pelaksanaan adalah mengenai pendistribusian manfaat dan keuntungan dimana pada Desa Non HID prosentase responden yang ragu-ragu jauh lebih besar yakni sebanyak 29,31\%.

Pada tahap operasi dan pemeliharaan, Terdapat perbedaan yang cukup signifikan antara Desa HID dengan Desa Non HID. Pertama, masih tingginya keraguan responden di Desa Non HID terhadap warga pemanfaat sarana untuk membayar iuran pengelolaan tepat waktu hampir semperlima dari responden (20,69\%). Kedua, jawaban responden terhadap inisiatif untuk segera memperbaiki sarana jika terjadi kerusakan dengan jawaban tidak setuju sebanyak 32,76\%. Dalam kegiatan pemantaun tidak terjadi perbedaan yang mencolok antara Desa HID dengan Desa Non HID.

\section{Analisis Tingkat Partisipasi Masyarakat}

Untuk menganalisis tingkat partisipasi masyarakat pada tahap perencanaan, implementasi, serta operasi dan pemeliharaan dalam Program PAMSIMAS di desa yang mendapat HID (Desa 
Garunggang dan Desa Ulin) dan desa Non HID (Desa Pantai Ulin) dilakukan dengan analisis deskriptif kuantitatif menggunakan distribusi frekuensi. Tingkat partisipasi masyarakat diukur melalui penjumlahan skor dari variabel. Setelah semua skor variabel dijumlah lalu dikaji partisipasi masyarakat masuk dalam kategori lima tingkatan partisipasi Nabel Hamdi sebagai berikut : Tidak Ada (non); Tidak Langsung (indirect); Konsultatif (consultative); Pengendalian Terbagi (shared control); dan Pengendalian Penuh (full control).

Kategori tingkat partisipasi masyarakat secara menyeluruh didasarkan pada skor tingkat partisipasi individu dikalikan dengan jumlah sampel. Variabel yang akan dianalisis adalah variabel yang telah ditentukan sebelumnya pada bab kajian pustaka yang meliputi semua tahapan kegiatan sejak dari perencanaan, implementasi, serta operasi dan pemeliharaan. Pada tahap perencanaan variabel yang dinilai adalah : tingkat kehadiran dalam pertemuan; keaktifan mengemukakan saran/usul; keterlibatan dalam menentukan konsep rencana; dan keterlibatan memberi persetujuan terhadap rancangan rencana. Variabel pada tahap implementasi adalah : keterlibatan dalam fisik pelaksanaan; dan keterlibatan dalam kepengurusan pelaksanaan. Sedangkan pada tahap operasi dan pemeliharaan variabel yang diteliti adalah : kesediaan membayar iuran; keterlibatan dalam fisik pemeliharaan; dan keterlibatan dalam kepengurusan pengelolaan.

Menurut hasil analisis meskipun secara umum tingkat partisipasi pada tahap perencanaan dan implementasi adalah sama, namun ternyata secara keseluruhan tingkat partisipasi pada ketiga desa yang diteliti terdapat perbedaan. Pada Desa HID yaitu Desa Garunggang dan Desa Ulin tingkat partisipasi sudah mencapai tingkat pengendalian terbagi (shared control), sedangkan pada Desa Non HID hanya mencapai derajat konsultatif (consultative).

\section{Analisis Komprehensif Partisipasi Masyarakat}

Analisis ini bertujuan untuk mengetahui hubungan antara tingkat partisipasi masyarakat dengan kondisi pelaksanaan, dengan cara membandingkan pelaksanaan partisipasi pada Desa HID dengan Desa Non HID serta karakteristik rmasyarakat yang mempengaruhinya. Pada Desa HID, karakteristik masyarakat mempunyai pengaruh yang kuat dalam setiap tahapan partisipasi. Pada tahap perencanaan, karakteristik masyarakat yang mempengaruhi adalah tingkat pendidikan yang telah dibuktikan dengan hasil uji statistik. Tingkat pendidikan rata-rata pada Desa HID lebih tinggi dari Desa Non HID. Dengan tingkat pendidikan yang tinggi seseorang lebih mempunyai pengetahuan dalam hal merencanakan kegiatan serta lebih mudah menyaring pengaruh dari luar. Untuk tahap implementasi karakteristik masyarakat yang berpengaruh kuat pada tahap ini adalah usia, pekerjaan dan penghasilan yang dibuktikan dengan hasil uji statistik. Rata-rata usia pada Desa HID lebih merata sehingga tidak ada senioritas dalam partisipasi dan pembagian keuntungan dapat lebih merata. Sedangkan pada tahap operasi dan pemeliharaan tingkat rata-rata pendidikan lebih tinggi dibanding Desa Non HID. Kesadaran akan pentingnya suatu tahapan kegiatan, dalam hal ini pengelolaan berbanding lurus dengan tingkat pengetahuan dan pendidikan.

Karakteristik masyarakat yang lebih beragam pada Desa Non HID justru tidak mempunyai pengaruh kuat terhadap kondisi pelaksanaan partisipasi. Kondisi yang terjadi disebabkan dalam pendekatan partisipatif tidak terjadi secara maksimal pertukaran gagasan (sharing idea), jalin kepentingan (knitting interest) dan pemaduan karya (synergy of action) diantara stakeholders, terutama pemberian kesempatan kepada masyarakat lokal untuk terlibat dalam pelaksanaan program (Niem Chaipan \& Thallister, Checkoway, Mitlin \& Thompson dalam Budiati, 2006). Dengan adanya sharing idea yang maksimal, sesuai dengan prinsip partisipasi akan lebih memungkinkan terbangunnya kerjasama antara rakyat dan pemerintah dalam 
merencanakan, melaksanakan dan mengembangkan hasilnya (Soetrisno, 1995:207), sehingga pengaruh-pengaruh dari luar yang kurang baik akan lebih mudah tersaring. Adanya knitting interest diantara stakeholder pada Desa Non HID, masyarakat akan lebih mengerti tentang faktor manfaat sehingga pendistribusian manfaat dan keuntungan dari kegiatan dapat dilaksanakan secara proporsional. Melalui synergy of action, dilakukan pemberian peran serta aktif masyarakat sejak dari proses perencanaan, pelaksanaan, pengawasan dan pengelolaan yang berkesinambungan sehingga akan lebih mudah untuk membangun kesadaran warga dalam membayar iuran pengelolaan dan insiatif untuk memperbaiki jika terjadi kerusakan. Dari hasil-hasil Program Penyediaan Air Minum dan Sanitasi Berbasis Masyarakat (PAMSIMAS) di Kecamatan Simpur pada khususnya dan Kabupaten Hulu Sungai Selatan pada umumnya.

\section{KESIMPULAN}

Berdasarkan uraian di atas disimpulkan bahwa faktor yang menyebabkan pelaksanaan partisipasi pada Desa HID dapat berjalan optimal adalah karena karakteristik masyarakat yang kuat dan berpengaruh dalam setiap tahapan program sehingga terbentuk kekuatan bersama untuk membangun dan target keberhasilan program PAMSIMAS dapat lebih mudah dicapai, serta tingkat partisipasi pada tahap pengelolaan sudah mencapai tingkat pengendalian penuh (full control). Sedangkan pada Desa Non HID karakteristik masyakarat tidak mempunyai pengaruh yang kuat terhadap kondisi pelaksanaan partisipasi dan terjadi kelemahan dalam pengimplementasian partisipasi masyarakat dalam setiap tahapan Program PAMSIMAS, serta tingkat partisipasi pada tahap operasi dan pemeliharaan yang lebih rendah dibanding Desa HID. Faktor yang menyebabkan kelemahan pengimplementasian partisipasi masyarakat pada Desa Non HID adalah masih belum maksimalnya pertukaran gagasan (sharing idea), jalin kepentingan (knitting interest) dan pemaduan karya (synergy of action). Dengan demikian pencapaian target program sebagai cerminan keberhasilan akan lebih sulit untuk dicapai.

\section{DAFTAR PUSTAKA}

Budiati, Lilin. 2006. "Penerapan co-Management dalam Pengelolaan Lingkungan Menuju Pembangunan Berkelanjutan di DAS Babon Jawa Tengah." Disertasi tidak diterbitkan, Program Doktor Ilmu Lingkungan Universitas Gadjah Mada, Yogyakarta. . 2012. Good Governance dalam Pengelolaan Lingkungan Hidup. Bogor: Ghalia Indonesia.

Departemen Pekerjaan Umum. 2011. "Pedoman Teknis Pelaksanaan Program PAMSIMAS di Masyarakat." Program Penyediaan Air Minum dan Sanitasi Berbasis Masyarakat, Jakarta.

Hamdi, Nabeel and Reinhard Goethert. 1997. Action Planning for Cities, "A Guide to Community Practice". New York: John Wiley \& Son.

Kabupaten Hulu Sungai Selatan dalam Angka Tahun 2010. Kantor Statistik Hulu Sungai Selatan, 2010.

Monografi Desa Garunggang Tahun 2010. Kantor Kecamatan Simpur. 2010.

Monografi Desa Pantai Ulin Tahun 2010. Kantor Kecamatan Simpur. 2010.

Monografi Desa Ulin Tahun 2010. Kantor Kecamatan Simpur.2010.

Rencana Tata Ruang Wilayah Kabupaten Hulu Sungai Selatan Tahun 2003-2013. Badan Perencanaan Pembangunan Daerah Hulu Sungai Selatan, 2003.

Soetrisno, Lukman. 1995. Menuju Masyarakat Partisipatif. Jakarta: Kanisius.

Suciati. 2006. "Partisipasi Masyrakat dalam Penyusunan Rencana Umum Tata Ruang Kota Pati." Tesis tidak diterbitkan, Program Studi Magister Teknik Pembangunan Wilayah dan Kota Universitas Diponegoro, Semarang. 